\title{
Black Lives Matter in Science Engineering and Medicine
}

\author{
Cato T. Laurencin, M.D., Ph.D.: Winner of the 2020 Herbert W. Nickens Award of the Association \\ of American Medical Colleges, Acceptance Remarks
}

\section{Cato T. Laurencin ${ }^{1}$ (D)}

Received: 30 October 2020 / Revised: 30 October 2020 / Accepted: 3 November 2020 / Published online: 18 November 2020

(C) W. Montague Cobb-NMA Health Institute 2020

\begin{abstract}
Addressing racism is key in moving forward as a nation and creating a more equitable environment. Within this paper, Cato T. Laurencin, M.D., Ph.D. describes the critical need to shift from diversity, inclusion, and equity (D.I.E.) to inclusion, diversity, equity, anti-racism, and learning (I.D.E.A.L.)
\end{abstract}

Keywords Racism · Anti-racism · Blackness · Anti-Blackness · Anti-Black · Ideal · Black · lives · Matter · Too · Diversity · Equity $\cdot$ Learning $\cdot$ Inclusion

Good afternoon. I'm Dr. Cato Laurencin, and I am the University Professor and Albert and Wilda Van Dusen Distinguished Endowed Professor of Orthopedic Surgery at the University of Connecticut. I am very proud to have received the Herbert W. Nickens Award of the American Association of Medical Colleges (the AAMC). I am equally proud to be able to provide this award lecture.

The title of my lecture is "Black Lives Matter Too in Science, Engineering, and Medicine."

The death of George Floyd and so many, many others has provided new information and a new awakening on issues of racism in America. We've seen, in many ways, what amounts to a sea change in an understanding and appreciation of racism and its effects on America [1].

When we use the term sea change, we are referring to a substantial change in perspective, which affects a society at large on a particular issue, and it can be considered to be similar to a paradigm shift. The term evolved from an older terminology meaning "change wrought by the sea." [1]

If we examine what's happening in terms of racism in America, one way is to examine Google searches. This slide shows the Google search activity for the term racism, either

Cato T. Laurencin

laurencin@uchc.edu

1 The Connecticut Convergence Institute for Translation in Regenerative Engineering, University of Connecticut Health, Farmington, CT 06032, USA the word itself or expanded versions, such as "what is racism" (Fig. 1).

What we see is that interest in concepts around racism tends to drop off every year in the summer, probably during vacation time, and the peaks are inconsistent, or less consistent, but they appear in November and April, and this is thought to be due partly to elections and primaries [2].

What we do see is a sea change in levels of interest and concern about racism. This chart shows the tracking of racism searches before and after the passing of George Floyd since the start of 2020 (Fig. 2).

What we can see is that there was a dramatic increase in searches after George Floyd died on May 25th of this year. Levels subsequently have moved to approximately $40 \%$ of the year's peak. Importantly, that $40 \%$ level is still over 6 times higher than the median interest in racism before May 25th [2]. So we are seeing a dramatic shift in concern and a desire for better understanding, in my opinion, regarding racism taking place in America.

The main thesis of my lecture today is that to truly combat health disparities in Blacks and to truly have Black diversity and equity exist, we must understand and combat racism. I'm going to provide a number of different articles that I've written over the years examining the intersection of health disparities, diversity, and racism. A paper I wrote called "Diversity 5.0: A Way Forward" describes the importance of combating racism if we are serious about moving forward with diversity [3]. The editorial entitled "The context of diversity," a piece I wrote in Science, which I'll refer to during my talk, discusses the need 


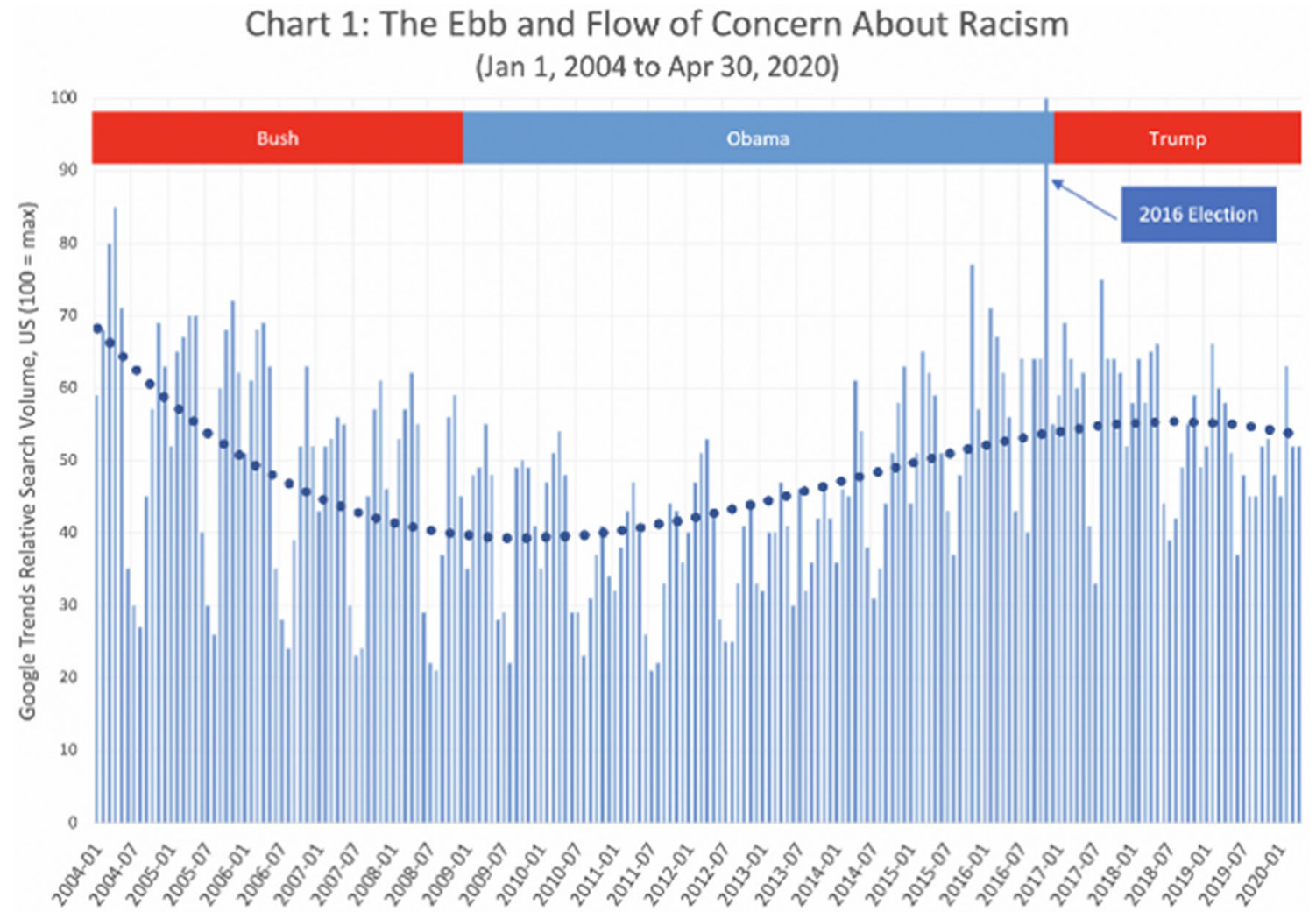

Fig. 1 Shows Google search activity for the term "racism," either the word itself or expanded versions such as "what is racism?"

to again combat racism in terms of achieving diversity and the need for more precision in using the term diversity [4].

"Racial Profiling Is a Public Health and Health Disparities Issue" was a paper that I recently wrote about racial profiling and its health effects on Black people and "A Pandemic on a Pandemic," a piece I wrote on racism and COVID-19 in Blacks in the Journal Cell Systems, refers to the disparities taking place in COVID-19 and their root causes of racism [5-6]. Then in a new paper entitled Just in Time: Trauma Informed Medical Education, we discuss how bias and discrimination in our medical education establishments creates an unhealthy place to grow academically [7]. We adapt principles the trauma informed approach, first realizing this is occurring, recognizing the effects of bias and discrimination
Fig. 2 Shows the sea change after the passing of George Floyd, tracking racism searches since the start of 2020

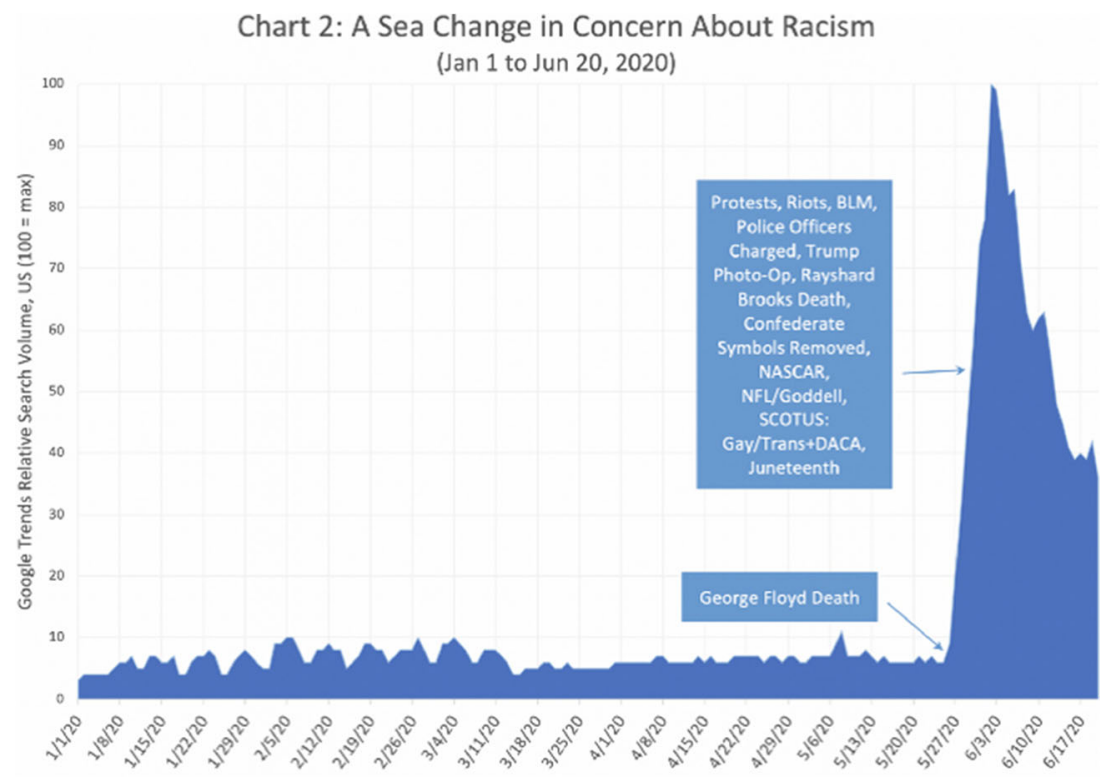


on students and trainees, responding with appropriate actions and resisting re-traumatization by creating a universal precaution environment, and by addressing those who promulgate bias, discrimination, and racism.

In my lecture, I'd like to talk about racism and its history in America. I'd then like to talk about racism and its effects on the present day. I will discuss our modern definitions of racism, then how messages of racism continue to manifest themselves. My lecture will then discuss racial disparities and the correlates to racism. I will discuss allostatic load and racism. I'd then like to end by describing and discussing my new vision of the ideal pathway for us to pursue in terms of creating a just and diverse society (Fig. 3)

Disparities in health care among Blacks have been known for a great deal of time. A landmark study done by the Institute of Medicine, now the National Academy of Medicine, produced very important study proceedings called "Unequal Treatment: Confronting Racial and Ethnic Health Disparities in Health Care." A key finding of the study was that racial discrimination was the major factor contributing to disparities in care in the setting of equal access [8].

To quote from the Institute of Medicine report, "There is considerable empirical evidence that even well-intentioned whites who are not overtly biased and who do not believe they are prejudiced, typically demonstrate unconscious implicit negative racial attitudes and stereotypes." [ 8] A number of studies that they quoted in their study referred to this.

In one study examining Medicare beneficiaries enrolled in managed care plans, African-Americans were found to receive poorer quality of care in a variety of measures. This is very important because individuals in Medicare managed care plans will have equal access to care. This is a paper by Schneider that was published in JAMA [9].

Ryn and Burke found that doctors were more likely to ascribe negative racial stereotypes to their minority patients, despite controlling for differences in minority and non-

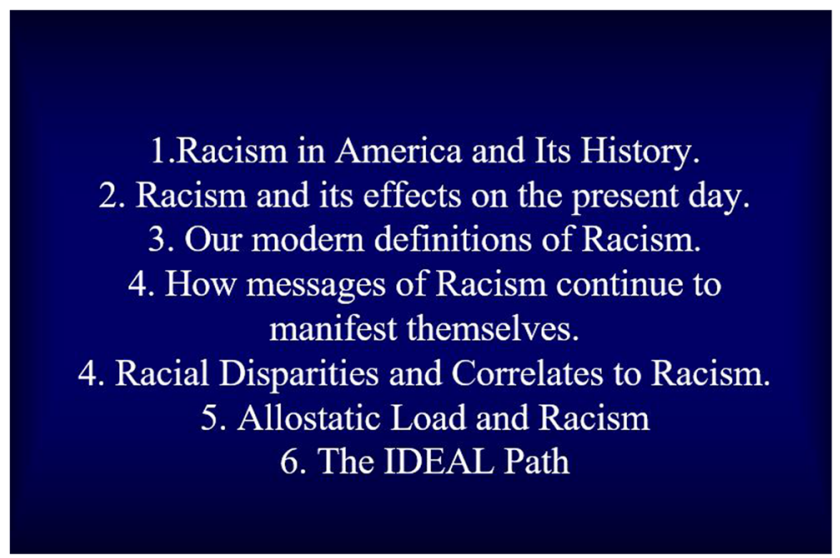

Fig. 3 Shows Dr. Cato T. Laurencin outline to a just and diverse society, otherwise known as the inclusion, diversity, equity, anti-racism and learning (IDEAL) pathway minority patients' education, income, and personality characteristics [10]. Green et al. found the first evidence of unconscious implicit racial bias among physicians using a measure of implicit social recognition and described its predictive validity [11].

The results of the Green study suggested that physicians' unconscious biases may contribute to racial and ethnic health disparities in the use of medical procedures such as thrombolysis in the treatment of myocardial infarction. The use of implicit bias testing has been done in a number of different settings after the study by Green, and by and large, has consistently found that these biases take place [11].

Unequal Treatment by the Institute of Medicine found that there is considerable empirical evidence that even wellintentioned whites who are not overtly biased and who do not believe they are prejudiced, typically demonstrate unconscious implicit negative racial attitudes and stereotypes [ 8]. Where else do we see the evidence of bias and racial discrimination against Blacks?

First, we can see where we have been as Black people in America...the cruelty of enslavement. I show a picture of a slave auction house here from the past [12]. (Fig. 4).

The profound history of degradation of Black enslavement was followed by the rise and eventual fall of Jim Crow. Emancipation ended slavery, but not its legacy.

Interestingly, Jim Crow was not a person, yet affected the lives of millions of people. This was named after a popular nineteenth century minstrel song that stereotyped Black people. Jim Crow came to personify the system of governmentsanctioned racial oppression and segregation in the USA. I refer you to the pbs.org website on Jim Crow on the rise and fall of Jim Crow as an era [ 13].

Next came the Second Reconstruction that ended with the passage of the Voting Rights Act of 1965. During the period from the end of World War II until the late 1960s, referred to as the Second Reconstruction, the nation began to correct civil and human rights abuses that continued in American society for over a century.

These changes were really led by very courageous people in the civil rights movement. People like Rosa Parks who famously refused to give up her seat to a white passenger on a public bus in 1955 . Her act of civil disobedience really galvanized the US civil rights movement in making the changes that were necessary.

So the struggles of Black folks from slavery and legislated inequality have gone on from 1619 to 1965 and we must never forget. We must never forget the struggles that have taken place. This is a slide from a history book, a version of a history book that said the Atlantic slave trade between the 1500s and 1800s brought millions of workers from Africa to the southern USA to work on agricultural plantations [14] (Fig. 5).

It's important that there is not a revisionist history of slavery and the degradations that took place during time. 
Fig. 4 Shows "China, Glass, Auction \& Negro Sales" in Atlanta, Georgia (1864) Photo by George N. Gardner

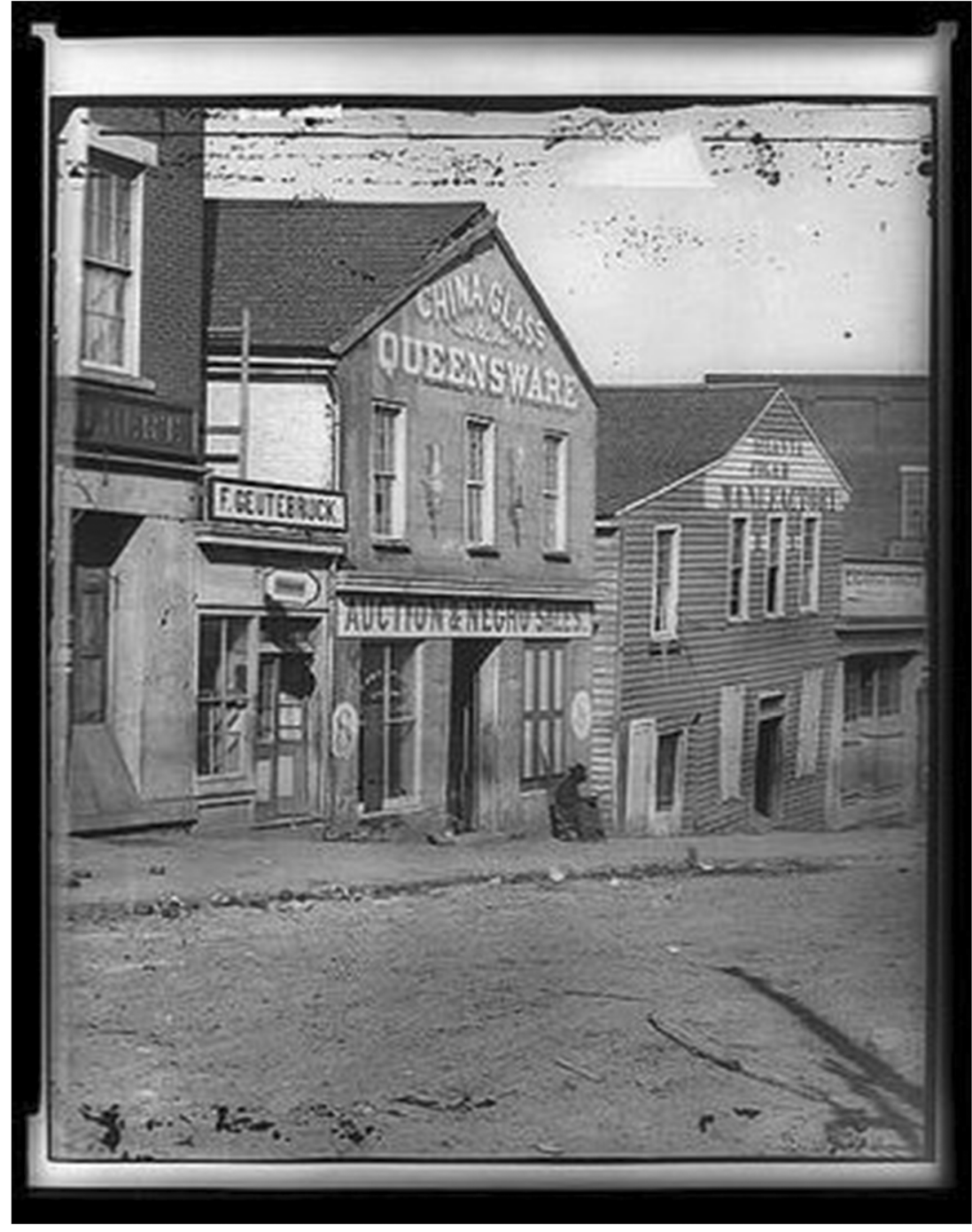

In the history of Black people in America, slavery and legislated inequality represent $85 \%$ of our history. There is much work that needs to be done to address, course correct, and move in right direction, as $85 \%$ of our history has been with slavery and legislated inequality.

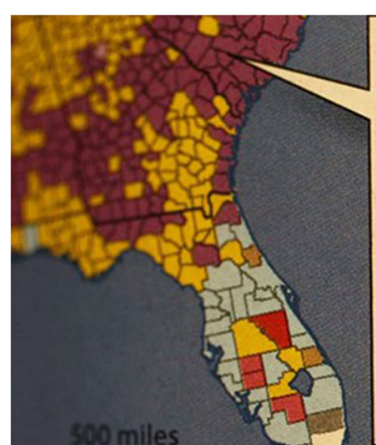

$$
\begin{aligned}
& \text { The Atlantic Slave } \\
& \text { Trade between the } \\
& 1500 \text { s and } 1800 \text { s } \\
& \text { brought millions } \\
& \text { of workers from } \\
& \text { Africa to the } \\
& \text { southern United } \\
& \text { States to work } \\
& \text { on agricultural } \\
& \text { plantations. }
\end{aligned}
$$

Fig. 5 Shows an image from a history book that demonstrates the Atlantic slave trade between the 1500 s and 1800 s which brought millions of workers from Africa to the southern USA to work on agricultural plantations
Well, where are we now? Racism is a major driver of our culture. We can see it in the clothes and messaging placed on this young man. We can see it in messaging on food advertisements. This is a slide of a cereal box in which the only Black face or Brown face in the group is cleaning the floor (Fig. 6) [15].

This was recently received by my wife. It was an advertisement from Barnes and Noble where one can choose The Bad Seed or The Good Egg as a book for children [16]. As one can see, the messaging is that the bad seed is a black seed, and the good seed is a white egg. In America, we are bombarded with messaging regarding race in subtle and not so subtle ways (Fig. 7).

In discussing racism, I refer you to the great work of Dr. Camara Jones on levels of racism and her theoretical framework discussed in "A Gardener's Tale" where she eloquently defines the different types of racism and provides allegories as to how they are caused and what their manifestations are. Institutional racism is defined by her as differential access to 
Fig. 6 Shows an image of a cereal box in which the only Black face or Brown face in the group is cleaning the floor, a clear racial message

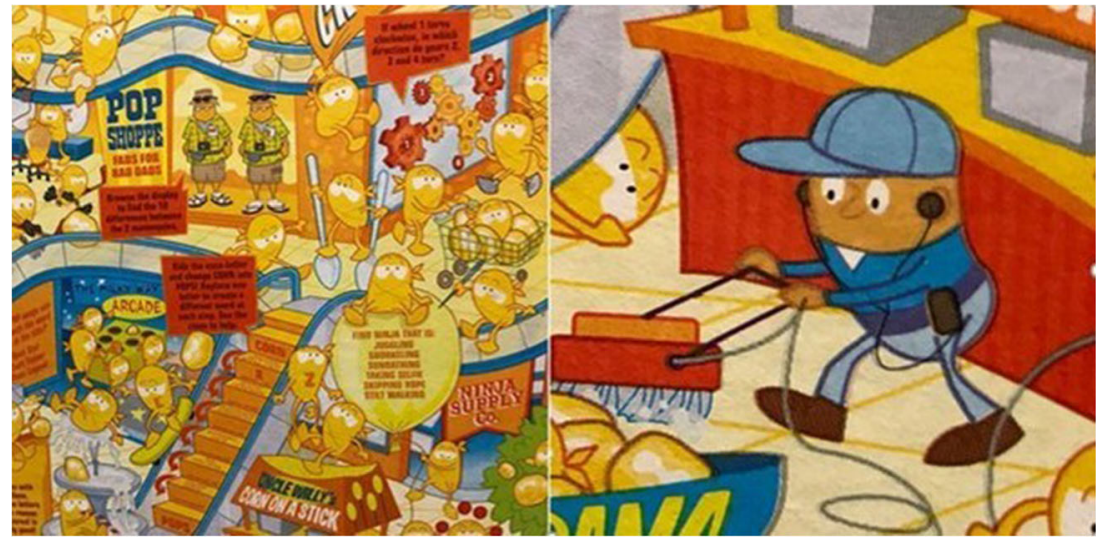

the goods, services, and opportunities by race. Institutional racism is often evident as inaction in the face of need. With institutionalized racism, there is an initial historical insult. There are structural barriers. There is, as she said, inaction in the face of need. As a part of the result, there is unearned privilege that takes place [17].

There is personally mediated racism with prejudice and discrimination [17]. Prejudice means differential assumptions
Fig. 7 Shows an advertisement received from Barnes \& Noble which demonstrates the subtle and not so subtle race messaging conveying that the bad seed is a black seed, and the good seed is a white egg

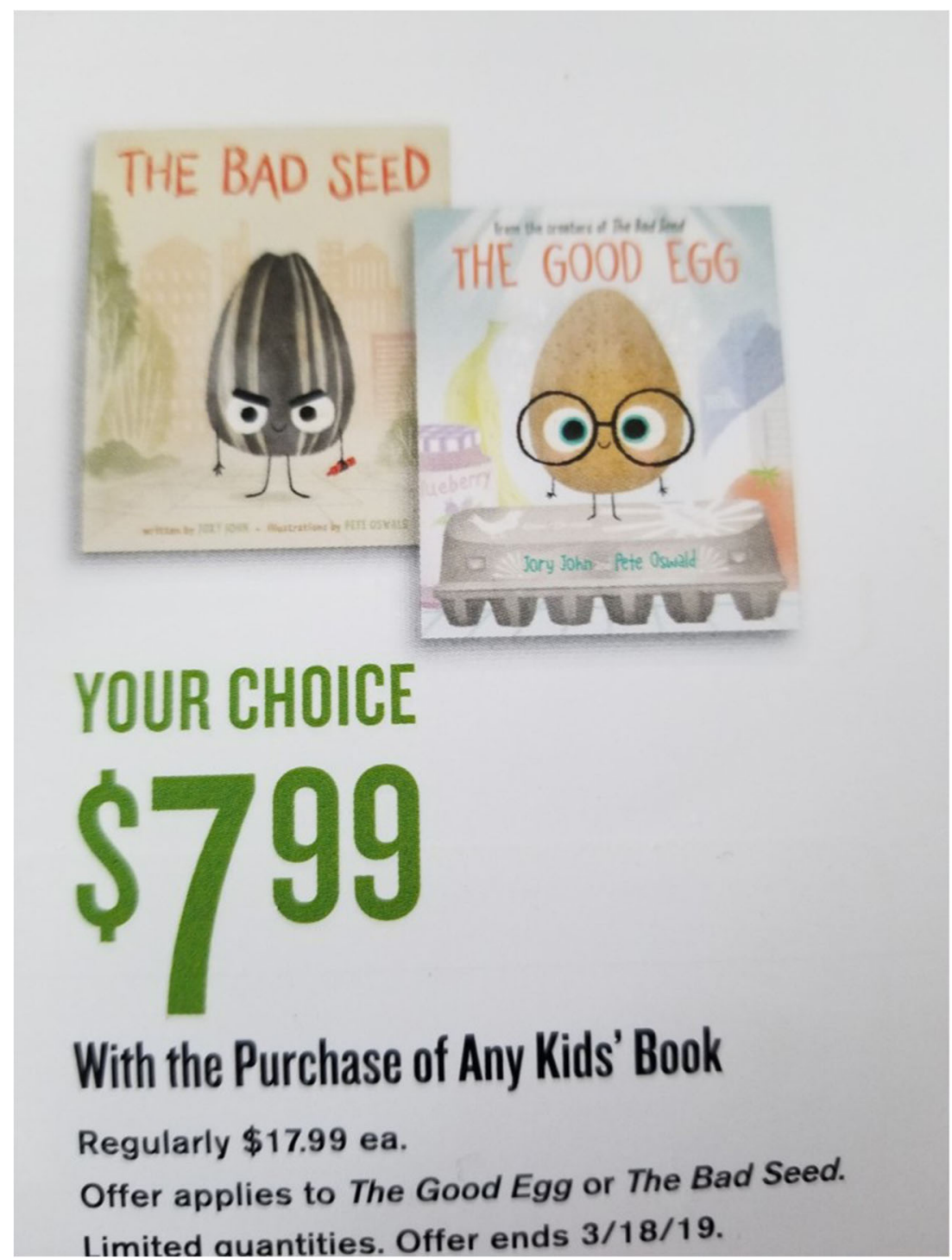


about the abilities, motives, and intentions in others according to race. Discrimination means differential actions towards others according to race. This is commonly thought of in the term we know as racism.

As Dr. Jones discusses, personally mediated racism can be intentional or unintentional. It can involve acts of commission, or acts of omission. It maintains structural barriers and societal norms condone it [17].

The third type of racism is internalized racism. It is defined as acceptance by members of the stigmatized race of negative messages about their own abilities and intrinsic worth. It's characterized by their not believing in others who look like them and not believing in themselves. Internalized racism reflects societal values. It erodes the individual sense of value and undermines the collective actions of the group [17].

Where else do we see evidence of bias and racial discrimination? Well, there are two examples that I think are important to note in our modern times. One is a struck down North Carolina voter ID law. This is a slide regarding the Supreme Court blocking a North Carolina voter ID law. A deadlocked Supreme Court refused to revive parts of a law, found to "target African-Americans with almost surgical precision." [ 18] The latest news is that this year, an appeals court blocked yet another attempt to disenfranchise Black voters and it is unlikely now that new restrictions will be in place in time for the upcoming election.

The Ally Bank case is a very well-known and famous case where a large settlement was made by Ally Bank to pay for a car loan bias. In the Ally bank case, individuals who were Black and Brown were charged higher interest rates than their scores indicated they should pay. The profit was split between Ally Bank and also the dealers, clearly an example of racism and discrimination taking place [19].

I sit on the Racial Profiling Prohibition Project Advisory Board for the State of Connecticut where we review data on disparities taking place in terms of traffic stops involving Black and Brown people. We know that nationally in reviewing Justice Department statistics, Black driver is $31 \%$ more likely to be pulled over than a White driver and $23 \%$ more likely than a Hispanic driver to be pulled over. In Connecticut, Black drivers are pulled over at higher rates for "pretext stops" (e.g., air freshener in rear view mirror, license plate abnormalities) than white drivers. The cars of Black drivers are searched at higher rates than white drivers, and those searches result in contraband at lower rates than white drivers [20].

We've talked about the outside world. What about in terms of science, engineering, and medicine? I had the privilege of working on the Advisory Committee to the Director which had a working group on Diversity in the Biomedical Research Workforce. As discussed in the Chronicle of Higher Education, NIH allocated \$31 million to tackle the racial gaps in training [21].
While there were a number of reasons why the racial gaps are taking place, there was also a disturbing discrepancy in success rates for research grants in applications from white and Black investigators. As reported by Ginther et al., this was found even after controlling for numerous observable variables [22]. While funding for increasing the number of investigators who can apply for grants is important and laudable, how discrimination and racism play a role in science and applications for federal funding must be studied further.

In clinical care, we know that there is a gap in terms of Black and white mortality. Between 1970 and 2004, it is estimated that 2.7 million excess Black deaths took place, making racism a more potent killer than prostate cancer, breast cancer, or colon cancer [23]. We know that combating racism can make a difference in the health of Blacks in America.

There's also the concept outside of the clinical setting, of just living as a Black person. Some people call it breathing while Black. This can be considered in the context of the allostatic load.

The allostatic load represents wear and tear on the body, which increases over time as an individual is exposed to repeated or chronic stress [24]. It represents a cycle of physiological consequences of chronic exposure to fluctuating or heightened neural and neuroendocrine responses that results from repeated or chronic stress. This term was coined by McEwen and Stellar in 1993 [25].

I serve as the Editor in Chief of the Journal of Racial and Ethnic Health Disparities. We published an important paper on racial discrimination and stigma consciousness associated with high blood pressure and hypertension in minority men. Stigma consciousness refers to individual differences in the extent to which targets believed that their stereotyped status pervades their interactions with members of other groups [26].

In this study, lifetime racial discrimination and stigma consciousness were examined to ascertain associations with blood pressure in minority and white middle-aged and older white men. The conclusion was that discrimination and stigma consciousness were associated with common risk factors for chronic disease and premature death that disproportionately affect minorities [26].

Another study that was published in the Journal of the National Medical Association found that allostatic load burden can influence racial health disparities in levels of mortality. In this study, allostatic load burden partially explained higher mortality levels among Blacks independent of socioeconomic status and also health behaviors [27].

So how does the Allostatic load manifest itself as a Black person on a day-to-day basis? I am formally a professor at the University of Virginia and travel back to the area every couple of years. During my last visit, I saw an unprecedented number of bumper stickers all through my time driving through central Virginia portraying the Confederate flag. The Confederate flag for me hearkens back a time of enslavement, Jim Crow, 
and continued racism. As a Black person, these may not only have personal emotional effects, but wear and tear health effects.

An article in the American Journal of Hypertension examined whether there was an association between race consciousness and the patient-physician relationship, medication adherence, and blood pressure in urban primary care of patients. In this study that was done by Dr. Lisa Cooper, along with Dr. Camara Jones, race consciousness was defined as the constant psychological vigil and heightened physiological response associated with racial discrimination among Blacks. The hypothesis was that race consciousness could increase their risk of hypertension. What they found was that, among Blacks, race consciousness was associated with a higher diastolic pressure [28].

Where else have we seen dramatic health disparities take place? We've seen it in HIV/AIDS in the African-American community. I wrote a paper entitled "HIV/AIDS and the African-American Community 2018- a Decade Call to Action." As we know with recent statistics, Blacks represent, approximately, $13 \%$ of the US population, but in terms of diagnosed cases, $44 \%$ of the estimated new HIV diagnoses [29].

An important study by clinicians at Johns Hopkins found that, at the height of the rise of HIV/AIDS, Blacks were treated differently than whites in regard to antiviral prescribing. This was found in the setting of equal access and controlling for socioeconomic status. This raises the idea that the rapid increase in numbers of Blacks with HIV may be partly explained by differential treatment and racism that took place during that period of time [30].

$\mathrm{CDC}$ projections right now are that 1 in 20 Black men will be HIV positive. One in 48 Black women will be HIV positive. One in 2 Black men who have sex with men will be HIV positive. One in 11 white gay and bisexual men will be HIV positive and 1 in 99 Americans overall will be HIV positive [31]. HIV is at crisis levels in the Black community and so we must continue to address.

The Black male in America is particularly affected and at risk in a number of different ways. We've talked about HIV/ AIDS, but let us discuss incarceration, America incarcerates people. Americans are $5 \%$ of the population, and $25 \%$ of the people incarcerated in the world [32]. Parenthetically many of the countries with the lowest numbers of incarcerated individuals are actually on the continent of Africa.

When we think about incarceration, right now $33 \%$ of those incarcerated in the USA are Black, way more than their proportion in the population [33]. Even beyond our discussion in terms of Black male incarceration, there is extensive data showing a punishing reach of racism for Black boys. New data shows that $21 \%$ of Black men that were raised at the bottom of the socioeconomic order were incarcerated according to a snapshot of a single day during the 2010 census [ 34].
An important study noted that the sons of Black families from the top $1 \%$ had about the same chance of being incarcerated on a given day as the sons of white families earning $\$ 36,000$. As noted by Ibram Kendi, one of the most popular liberal, post-racial ideas is that the fundamental problem is class, and not race [ 34]. Clearly this study explodes that idea.

I became very concerned about the fate of Black men in medicine. A number of studies and a number of our articles discussed the sharp drop in Black males in medical schools. In fact, one article said Black male doctors are becoming endangered [35]. They were, and they are.

We wrote a paper called "An American Crisis- the Lack of Black Men in Medicine," and then proceeded working with the National Academies on an initiative to be able to create a workshop on Black men in medicine [36]. We, along with the W. Montague Cobb/NMA Health Institute, moved forward with a National Academy of Sciences, Engineering, and Medicine workshop on The Growing Absence of Black Men in Medicine and Science: An American Crisis. The workshop proceedings are available online for free at the National Academies Press [37]. I had the honor of chairing the workshop and was Rapporteur for the proceedings.

In the workshop proceedings, Dr. Victor Dzau, the President of the National Academy of Medicine, stated "This alarming trend threatens the quality of our health system, hampers progress in improving health for all, and challenges equity and justice." Dr. Camara Jones wrote "Racism, this cultural morass of our nation, is a prime challenge and barrier for Black men along the trajectory." [ 37]

In discussing racism, one of the key effects that take place is a disregard, disrespect, and dismissal of Black people in America. Perhaps, this is why the Black Lives Matter movement has actually taken shape and grown because this is precisely what that movement is trying to address. The movement's purpose resonates with people, Black and white. So, as for racism, by naming it, learning about its past and present, and working to directly combat it, we may best address racialbased health disparities and also promote racial diversity.

Parenthetically, after our workshop that we had at the National Academy on Black men in medicine, we decided to move forward with a National Academies Roundtable on Black Men and Black Women in Science, Engineering, and Medicine. In my piece published in Science earlier this year, I wrote about the context of diversity and why we need initiatives such as this [ 4].

In the piece entitled "The Context of Diversity," I referred to the fact that there are many groups that are under the diversity umbrella. With so many groups, it becomes easier for diversity efforts to disregard the historical and present drivers of discrimination and racism that the concept of diversity began with. In my piece, I wrote, "In other words, the greater context of inclusion and equity can get lost, making strides to diversify meaningless." [ 4] 
I further wrote "This latter point is particularly relevant to Blacks in the United States who've experienced slavery, legally enforced segregation and discrimination, and now battle conscious and unconscious racism and mass incarceration. Institutionalized racism, past and present, has resulted in a disregard, disrespect, and dismissal of Black people from all walks of life. This is true in science, engineering, and medicine." [ 4]

So we have launched the Roundtable on Black Men and Black Women in Science, Engineering, and Medicine. I want to take this opportunity to thank the members of the steering committee who are on this slide, who first worked with me formulating this new entity.

These are the members of the roundtable (Fig. 8 a, b, and c).

There are 31 members, distinguished individuals, from across the country working in medicine, engineering, and science and who are like-minded in terms of the desire to move the needle forward quickly in addressing issues such as combating racism, improving health and promoting diversity.

At the heart of the roundtable are what we call action groups. The aim of these action groups are to foster information sharing and the development of evidence-based approaches, along with engagement with key stakeholders in the broader community of scientists, clinicians, engineers, and administrators. The group works to design and conduct workshops, write papers, and conduct activities for meaningful change.

We have seven action groups right now. The first to be formed was the conscious and unconscious bias action group, addressing how to operate and identify mechanisms for intervention. Second, a pre-K to grad education action group was formed, which identifies disparities in education and the educational pipeline. Third, there is a financing action group, which addresses the financial barriers to higher education and its impact. Fourth, there is a public advocacy, now called a public engagement action group, which determines how advocacy and public engagement can be utilized to bring issues of the roundtable to the forefront and to develop strategies for an increase in public awareness. Fifth, the mentoring and advising action group examines and presents ideas on mentorship programs and pathways. Sixth, an action group on psychological factors, examines the environment and stressors that take place with Black people in science, engineering, and medicine. Finally, a COVID-19 action group, examining COVID-19 in the Black community, has been formed.

The roundtable is responsible for conducting workshops, writing papers, and creating meaningful activities and the action groups serve as the backbone of the roundtable in its functions throughout the year. The group convened our first meeting in December, 2019, and we decided the first activity would be to discuss and address issues of racism.
So, our first action group workshop was on racism. On April 13th and 14th, the workshop on The Impacts of Racism and Bias on Black People Pursuing Careers in Science, Engineering, and Medicine took place. The workshop examined the role of racism and bias in the decline of Black students in science, engineering, and medicine. It explored the historical trends of enrollment of Black students in medical-, engineering-, and science-based schools, and also looked at ways to be able to address these issues.

This is the cover for the proceedings of the workshop (Fig. 9)

The Impacts of Racism and Bias on Black People Pursuing Careers in Science, Engineering, and Medicine. The workshop proceedings will soon be available on the National Academies Press website as an e-book for free [37].

Where should we be headed now? As I hope I am making clear, our understanding and appreciation of the impact of racism in America are vitally important. From there, an understanding of anti-Black racism taking place in America must be understood. Anti-Black racism is the specific kind of racial prejudice directed towards Black people.

There's a very important piece entitled "A Reflection on Anti-Black Racism" by Marlysa Gamblin that I'll be quoting and I refer you to the website in which it appears. "AntiBlackness," she writes "Devalues Blackness while systematically marginalizing Black people, the issues that affect us, and the institutions created to support us. The first form of antiBlackness is overt racism, which is upheld by covert structural and systemic racism that categorically predetermined the socioeconomic status of Blacks in this country. The second form of anti-Blackness is unethical disregard for Black people, as seen in the cases of police or civilian brutality against Black bodies." [ 38]

So what is the ideal path? I want to close by providing some of my vision for where I think we should move as a country in terms of issues of diversity and equity. Right now, discussions of diversity, inclusion, and equity are ubiquitous. While we have had some gains in these areas, they have not sufficiently addressed the issues of racism that we see in this country.

My belief is that we need to move to inclusion, diversity, equity, anti-racism, and learning (Fig. 10).

Anti-racism according to Wikipedia is "A form of action against racism, systemic racism and the oppression of marginalized groups. Being anti-racist is based on the conscious efforts and actions to provide equitable opportunities for all people on an individual and systemic level. People can act against racism by acknowledging personal privileges, confronting acts of racial discrimination and working to change personal racial biases." [ 39]

By learning, what do I mean? Understanding ways in which Black people are affected by the specific kinds of racial discrimination called anti-Blackness. Understanding the history of Black, Indigenous, and people of color. Moving from 


\section{The National Academies of SCIENCES $\cdot$ ENGINEERING $\cdot$ MEDICINE}

Roundtable on Black Men and Black Women in Science, Engineering, and Medicine

\author{
Cato Laurencin, MD, PhD (NAE/NAM) (chair)* \\ University Professor \\ University of Connecticut \\ Albert and Wilda Van Dusen Distinguished Professor \\ of Orthopaedic Surgery \\ Professor of Chemical, Materials and Biomolecular \\ Engineering \\ Director \\ Raymond and Beverly Sackler Center for \\ Biomedical, Biological, Physical and Engineering \\ Sciences \\ Chief Executive Officer \\ The Connecticut Convergence Institute for \\ Translation in Regenerative Engineering \\ Olujimi Ajijola, MD, PhD \\ Assistant Professor of Medicine \\ UCLA Cardiac Arrhythmia Center \\ David Geffren School of Medicine at UCLA \\ Mark Alexander, PhD \\ Secretary \\ National Executive Committee, Health and Wellness \\ 100 Black Men of America \\ Gilda Barabino, PhD (NAE) \\ Dean \& Daniel and Frances Berg Professor \\ Office of the Dean \\ The City College of the CUNY \\ Cedric Bright, MD, FACP * \\ Associate Dean for Admissions \\ Brody School of Medicine \\ East Carolina University \\ L.D. Britt, MD, MPH, D.Sc (Hon), FACS (NAM)* \\ Henry Ford Professor and Edward J. Brickhouse \\ Chairman \\ Department of Surgery \\ Eastern Virginia Medical School
}

\author{
Kimberly Bryant \\ Founder and Executive Director \\ Black Girls CODE \\ Theodore Corbin, MD, MPP \\ Associate Professor of Emergency Medicine \\ Drexel University \\ Andre Churchwell, MD \\ Chief Diversity Officer \\ Vanderbilt University Medical Center \\ Senior Associate Dean for Diversity Affairs \\ Vanderbilt University School of Medicine \\ Professor of Medicine (Cardiology) \\ Professor of Radiology and Radiological Sciences \\ Professor of Biomedical Engineering \\ George Q. Daley, MD, PhD (NAM)* \\ Dean of Faculty and Professor \\ Harvard Medical School \\ Wayne Frederick, MD, MBA \\ President \\ Howard University \\ Garth Graham, MD, MPH \\ President \\ Aetna Foundation
}

Paula T. Hammond, PhD (NAM/NAE)

David H. Koch Professor of Engineering

Department Head

Department of Chemical Engineering

MIT

Evelynn Hammonds, PhD, MS (NAM)

Barbara Gutmann Rosenkrantz Professor of

The History of Science

Professor of African and African American Studies

Chair, Dept of the History of Science

Harvard University

\section{* denotes Steering Committee member}

Fig. 8 a,b,c Display the current members of the Roundtable for Black Men and Black Women in Science, Engineering, and Medicine

just an ally to what I would call a ride or die partner in the antiracism movement, these are some of the ways that I believe learning can be used in a constructive way to bring about the ideal pathway to move forward. 


\section{The National Academies of SCIENCES $\cdot$ ENGINEERING $\cdot$ MEDICINE}

Ian Henry, PhD

Section Head, R\&D Analytical Chemist

Proctor and Gamble

Camara Phyllis Jones, MD, MPH, PhD

Senior Fellow

Satcher Health Leadership Institute and

Cardiovascular Research Institute

Adjunct Associate Professor

Dept of Community Health and Preventive Medicine Morehouse School of Medicine

Adjunct Professor

Dept of Epidemiology

Dept of Behavioral Sciences and Health Education

Rollins School of Publi $c$ Health

Emory University

Orlando Kirton, MD, FACS, MCCM, FCCP, MBA

Surgeon-in-Chief, Chairman of Surgery

Chief Division of General Surgery

Abington-Jefferson Health

Vice Chairman

Jefferson Health Enterprise Dept of Surgery

Professor of Surgery

Sidney Kimmel Medical College

Thomas Jefferson University

John Lumpkin, MD, MPH (NAM)

Senior Vice President

Robert Wood Johnson Foundation

Shirley Malcom, PhD, MA (NAS)

Directorate for Education and HR Programs

AAAS

Cora Bagley Marrett, MA, PhD

Emeritus Professor

Department of Social Sciences

University of Wisconsin-Madison

Alfred M. Mays, MS

Program Officer

Burroughs Welcome Fund

* denotes Steering Committee member

Fig. 8 (continued)
Valerie Montgomery Rice, MD (NAM)

President and Dean

Office of the President and Dean

Morehouse School of Medicine

Randall C. Morgan, MD, MBA *

Executive Director

W. Montague Cobb/NMA Health Institute

Elizabeth Ofili, MD, MPH, FACC (NAM)*

Senior Associate Dean, Clinical Research Director

Clinical Research Center

Morehouse School of Medicine

Vivian W. Pinn, MD (NAM)*

Senior Scientist Emerita

Fogarty International Center

Former Director (Retired)

Office of Research on Women's Health

National Institutes of Health

Joan Y. Reede, MD, MS, MPH (NAM)

Dean for Diversity and Community Partenership

Associate Professor of Medicine

Dept of Medicine

Harvard Medical School

Louis Sullivan, MD (NAM)*

President Emeritus

Morehouse School of Medicine

Lamont R. Terrell, PhD

Head, R \& D Talent and University Diversity

GlaxoSmithKline

Hannah Valentine, MD, PhD

Chief Officer for Scientific Workforce Diversity $\mathrm{NIH}$ 


\title{
The National Academies of SCIENCES • ENGINEERING • MEDICINE
}

\author{
FHFSA (NAM) \\ Vice Dean, Diversity and Inclusion \\ Magerstadt Professor of Medicine \\ Professor of Medical Social Sciences \\ Chief, Division of Cardiology \\ Feinberg School of Medicine \\ Northwestern University \\ Associate Director \\ Bluhm Cardiovascular Institute \\ Northwestern Memorial Hospital \\ Deputy Editor \\ JAMA Cardiology
}

Clyde W. Yancy, MD, MSc, MACC, FAHA, MACP,

Fig. 8 (continued)

I'm very proud of our university, the University of Connecticut. We have just initiated a US Anti-Black Racism course. That course, which is now taking place and being offered to all faculty, staff, and students, is a one-credit course on the foundational history and concepts related to systemic and anti-Black racism [40].

It's focused on the foundational concepts related to Black consciousness, Black resistance, Black resilience, and intersectional solidarity. It's particularly focused on the US context. It provides resources at UConn to continue the study, development, understanding, and potentially disrupting antiBlack racism for the collective good. Information on the course is available on the website of the Provost's Office at the University of Connecticut [40].

This is the type of learning environment that can promote diversity, equity, and inclusion for all. Addressing anti-racism is key in terms of moving forward as a nation and creating a more equitable environment. So let us move from diversity, 
PROCEEDINGS OF A WORKSHOP

\section{THE IMPACTS OF RACISM AND BIAS ON BLAKKPEOPLE PURSUING CAREERS IN SEIENCE, ENGINEERING, AND MEDICINE \\ The National Academies of \\ SCIENCES · ENGINEERING $\cdot$ MEDICINE}

Fig. 9 Shows the cover of the proceedings of the workshop on The Impacts of Racism and Bias on Black People Pursuing Careers in Science, Engineering, and Medicine hosted by the Roundtable for Black Men and Black Women in Science, Engineering, and Medicine

inclusion, and equity, to inclusion, diversity, equity, anti-racism, and learning (Fig. 11).

I believe that's the pathway to the future.

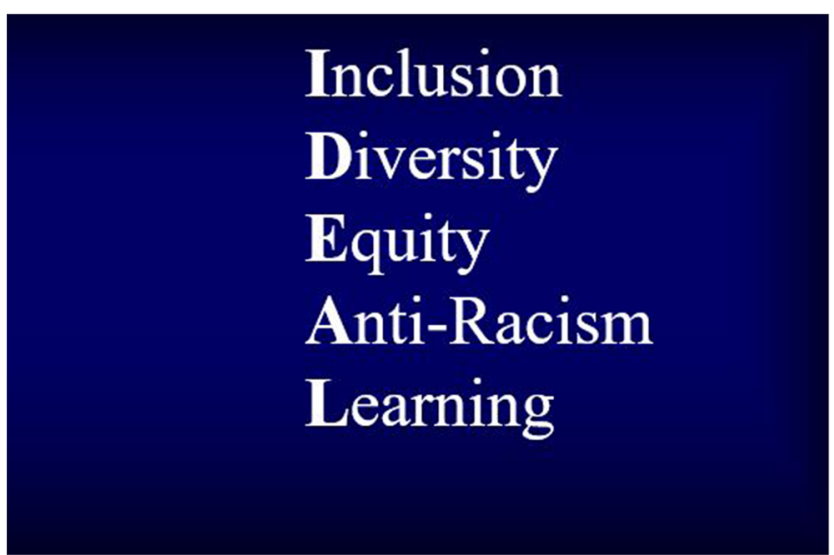

Fig. 10 Shows Dr. Cato T. Laurencin, M.D., Ph.D., IDEAL pathway to a just and diverse society

\section{Let's move from Diversity, Inclusion and Equity (DIE)}

to

\section{Inclusion, Diversity, Equity, Anti-} Racism, and Learning (IDEAL)

I want to again give thanks to all for bestowing upon me the Herbert W. Nickens Award [41]. In this lecture, I have outlined my hope and vision for combatting racial and ethnic health disparities. I hope to be able to work with individuals across the country in the area of inclusion, diversity, equity, anti-racism, and learning, as we put into place an ideal path for achieving a better society.

Thank you.

Acknowledgments The author would like to acknowledge the help of Melanie Burnat in preparing these remarks for publication.

Funding Dr. Cato T. Laurencin received support from the NIH BUILD Award TL4GM118971.

\section{Compliance with Ethical Standards}

Conflict of Interest The author declares that there is no conflict of interest.

\section{References}

1. Wikipedia contributors. (2019). Sea change (idiom). Wikipedia. https://en.wikipedia.org/wiki/Sea_change_(idiom). 12 Nov. 2020.

2. Blessington M (2020). America's Sea Change on Racism. Medium. https://medium.com/@mark.blessington/americas-sea-change-onracism-19358416c010. 12 Nov. 2020.

3. Laurencin CT (2014). Diversity 5.0: A Way Forward. Journal of racial and ethnic health disparities. https://link.springer.com/article/ $10.1007 / \mathrm{s} 40615-014-0023-5$ ? error=cookies_not supported \&code $=4 \mathrm{c} 0 \mathrm{ab} 6 \mathrm{~b} 0-4 \mathrm{a} 73-4 \mathrm{dc} 5-\mathrm{b} 683-784739 \mathrm{f} 073 \overline{17} .1 \overline{2}$ Nov. 2020.

4. Laurencin CT (2019). The context of diversity. Science. https:// science.sciencemag.org/content/366/6468/929.abstract. 12 Nov. 2020.

5. Laurencin CT. Racial profiling is a public health and health disparities issue. J Racial Ethn Health Disparities. 2020. https://doi.org/10.1007/s40615-020-00738-2?error=cookies 
not_supported \&code $=691$ e $670 b-47 a 4-44 d 6-b b c b-$ 09847 af88a53.

6. Laurencin CT A Pandemic on a Pandemic: Racism and COVID-19 in Blacks. (2020). PubMed Central (PMC). https://www.ncbi.nlm. nih.gov/pmc/articles/PMC7375320/. 12 Nov. 2020.

7. McClinton A, Laurencin CT. Just in TIME: Trauma-Informed Medical Education. J Racial Ethn Health Disparities. 2020. https://doi.org/10.1007/s40615-020-00881-w?error=cookies_not_ supported \&code $=$ cb4b3fe8-3dcc-49e1-8e97-f1 87de306b88.

8. Institute of Medicine (US) Committee on Understanding and Eliminating Racial and Ethnic Disparities in Health Care. (2003). Unequal Treatment: Confronting Racial and Ethnic Disparities in Health Care. PubMed. https://pubmed.ncbi.nlm.nih.gov/ 25032386/. 12 Nov. 2020.

9. Schneider EC (2002). Racial disparities in the quality of care for enrollees in Medicare managed care. https://pubmed.ncbi.nlm.nih. gov/11886320/. 12 Nov. 2020.

10. Ryn VM, \& Burke J (2000). The effect of patient race and socioeconomic status on physicians' perceptions of patients. https:// pubmed.ncbi.nlm.nih.gov/10695979/. 12 Nov. 2020.

11. Green A (2007). Implicit bias among physicians and its prediction of thrombolysis decisions for black and white patients. PubMed Central (PMC). https://www.ncbi.nlm.nih.gov/pmc/articles/ PMC2219763/. 12 Nov. 2020.

12. Barnard G (1864). ["Auction \& Negro Sales," Whitehall Street]. The Library of Congress. https://www.loc.gov/item/2018666988/. 12 Nov. 2020.

13. American Experience. (2011). Jim Crow Laws. American Experience | Official Site | PBS. https://www.pbs.org/wgbh/ americanexperience/features/freedom-riders-jim-crow-laws/. 12 Nov. 2020.

14. Wang Y (2015). Workers' or slaves? Textbook maker backtracks after mother's online complaint. Washington Post. https://www. washingtonpost.com/gdpr-consent/?next_url=https $\% 3 \mathrm{a} \% 2 \mathrm{f} \%$ $2 \mathrm{fwww}$.washingtonpost.com $\% 2$ fnews $\% 2$ fmorning-mix $\% 2 \mathrm{fwp} \%$ $2 \mathrm{f} 2015 \% 2 \mathrm{f} 10 \% 2 \mathrm{f} 05 \% 2$ fimmigrant-workers-or-slaves-textbookmaker-backtracks-after-mothers-online-complaint $\% 2$ f. 12 Nov. 2020.

15. Snider MUT (2017). Kellogg's to replace racially insensitive Corn Pops boxes following Twitter call out. USA TODAY. https://eu. usatoday.com/story/money/business/2017/10/25/kelloggs-replaceracially-insensitive-corn-pops-boxes-following-twitter-rant/ 797911001/. 12 Nov. 2020.

16. Delperdang J (2019). Check It Out: The Bad Seed \& The Good Egg Books by Jory John. KWIT. https://www.kwit.org/post/check-itout-bad-seed-good-egg-books-jory-john. 12 Nov. 2020.

17. Jones, C. (2000). Levels of racism: a theoretic framework and a gardener's tale. PubMed Central (PMC. https://www.ncbi.nlm. nih.gov/pmc/articles/PMC1446334/. 12 Nov. 2020.

18. Gallagher DA BACD (2020). North Carolina appeals court blocks voter ID law - CNNPolitics. CNN. https://edition.cnn.com/2020/ 02/18/politics/north-carolina-voter-id-law/index.html. 12 Nov. 2020.

19. Isidore, C. (2013). Ally to pay $\$ 98$ million to settle car loan discrimination probe. CNNMoney. https://money.cnn.com/2013/12/ 20/news/companies/ally-car-loan-discrimination/. 12 Nov. 2020.

20. Reports - CT Racial Profiling Prohibition Project. (2016). CT Racial Profiling Prohibition Project. http://www.ctrp3.org/reports/. 12 Nov. 2020.

21. Basken P (2014). NIH allocates \$31-million to tackle racial gaps in training. The Chronicle of Higher Education. https://www. chronicle.com/article/nih-allocates-31-million-to-tackle-racialgaps-in-training/. 12 Nov. 2020.
22. Ginther et al. (2012). RACE, ETHNICITY, AND NIH RESEARCH AWARDS. PubMed. https://www.ncbi.nlm.nih. gov/pmc/articles/PMC3412416/. 12 Nov. 2020.

23. White Coats for Black Lives. (2015). \#BlackLivesMatter: Physicians Must Stand for Racial Justice. J Ethics $\mid$ Am Med Assoc. https://journalofethics.ama-assn.org/article/ blacklivesmatter-physicians-must-stand-racial-justice/2015-10. 12 Nov. 2020.

24. Wikipedia contributors. (2020). Allostatic load. Wikipedia. https:// en.wikipedia.org/wiki/Allostatic load\#:\%7E:text=Allostatic\% 20load\%20is\%20\%22the\%20wear,McEwen\%20and $\% 20$ Stellar\% 20in\%201993. 12 Nov. 2020.

25. McEwen BS, \& Stellar E (1993). Stress and the individual. Mechanisms leading to disease. PubMed. https://pubmed.ncbi. nlm.nih.gov/8379800/. 12 Nov. 2020.

26. Orom H, Sharma C, Homish G, Underwood W, \& Homish D (2016). Racial discrimination and stigma consciousness are associated with higher blood pressure and hypertension in minority men. PubMed. https://pubmed.ncbi.nlm.nih.gov/27800597/. 12 Nov. 2020.

27. Duru O, Harawa N, Kermah D, \& Norris K (2012). Allostatic load burden and racial disparities in mortality. PubMed. https://www. ncbi.nlm.nih.gov/pmc/articles/PMC3417124/

28. Brewer L, Carson K, Williams D, Allen, A, Jones C, \& Cooper L (2013). Association of race consciousness with the patientphysician relationship, medication adherence, and blood pressure in urban primary care patients. PubMed. https://www.ncbi.nlm.nih. gov/pmc/articles/PMC3790452/. 12 Nov. 2020.

29. Laurencin CT, Murdock C, Laurencin L, Christensen D. HIV/AIDS and the African-American community 2018: a decade call to action. J Racial Ethn Health Disparities. 2018, June 4;5:449-58. https:// doi.org/10.1007/s40615-018-0491-0?error=cookies not supported\&code $=$ de $5 \mathrm{df3} 1 \mathrm{c}-4792-4 \mathrm{aca}-9127-7577 \mathrm{a} 8 \mathrm{c} 5060 \mathrm{~d}$.

30. Ribaudo H, Smith K, Robbins G, Flexner C, Haubrich R, Chen Y, Fischl M, Shackman B, Riddler S, \& Gulick R (2013). Racial differences in response to antiretroviral therapy for HIV infection: An AIDS Clinical Trials Group (ACTG) Study Analysis. PubMed. https://www.ncbi.nlm.nih.gov/pmc/articles/PMC3814827/. 12 Nov. 2020.

31. NCHHSTP Media Team. (2016). 2016 CROI press release: lifetime HIV risk | CDC. CDC. https://www.cdc.gov/nchhstp/newsroom/ 2016/croi-press-release-risk.html. 12 Nov. 2020.

32. Lee M (2015). Does the United States really have 5 percent of the world's population and one quarter of the world's prisoners? The Washington Post. https://www.washingtonpost.com/gdprconsent/?next url=https $\% 3 \mathrm{a} \% 2 \mathrm{f} \% 2 \mathrm{fwww}$.washingtonpost.com $\%$ 2 fnews $\% 2$ ffact-checker $\% 2$ fwp $\% 2$ f $2015 \% 2$ f04\% 2 f $30 \% 2$ fdoesthe-united-states-really-have-five-percent-of-worlds-populationand-one-quarter-of-the-worlds-prisoners\%2f. 12 Nov. 2020.

33. Gramlich J (2019). The gap between the number of blacks and whites in prison is shrinking. Pew Research Center. https://www. pewresearch.org/fact-tank/2019/04/30/shrinking-gap-betweennumber-of-blacks-and-whites-in-prison/. 12 Nov. 2020.

34. Badger E, Miller C, Pearce A, \& Quealy K (2018). Extensive data shows punishing reach of racism for black boys. The New York Times. https://www.nytimes.com/interactive/2018/03/19/upshot/ race-class-white-and-black-men.html. 12 Nov. 2020.

35. Tyeese D (2013). Are black male doctors becoming endangered? The Grio. https://thegrio.com/2013/03/05/are-black-male-doctorsbecoming-endangered/. 12 Nov. 2020.

36. Laurencin CT, \& Murray M (2018). An American Crisis: The lack of black men in medicine. PubMed. https://www.ncbi.nlm.nih.gov/ pmc/articles/PMC5909952/. 12 Nov. 2020. 
37. Laurencin CT (2018). An American crisis: the growing absence of black men in medicine and science: proceedings of a joint workshop. The National Academies Press. https://www.nap.edu/read/ 25130/chapter/. 12 Nov. 2020.

38. Gamblin $\mathrm{M}(2020)$. A reflection on anti-black racism. Bread for the World. https://www.bread.org/blog/reflection-anti-black-racism. 12 Nov. 2020.

39. Wikipedia contributors. (2020a). Anti-racism. Wikipedia. https:// en.wikipedia.org/wiki/Anti-racism. 12 Nov. 2020.
40. Ballestrini C (2020). U.S. Anti-Black Racism Course. Office of the Provost. https://provost.uconn.edu/us-anti-black-racism-course/. 12 Nov. 2020.

41. Herbert W Nickens Award. (2021). AAMC. https://www.aamc. org/what-we-do/aamc-awards/nickens. 12 Nov. 2020.

Publisher's Note Springer Nature remains neutral with regard to jurisdictional claims in published maps and institutional affiliations. 